\title{
Rising Trend of Caesarean Section in a Tertiary Hospital Over a Decade
}

\author{
R NAZNEEN $^{\mathrm{a}}$, RA BEGUM ${ }^{\mathrm{b}}$, K SULTANA ${ }^{\mathrm{c}}$
}

\begin{abstract}
:
Background information: Since the early 1990s, emergency obstetric care (EmOC) in Bangladesh has played important role to reduce the maternal mortality rate. Along with other indicators of improved maternal care, there is a trend of rising caesarean section rates over the last decade affecting the economy of the country. According to demographic and Health Surveys conducted between 1993 and 2004, rate of caesarean section has risen from $2 \%$ to $6 \%$ which is more pronounced in urban area.
\end{abstract}

Objective: To assess the indications and the trends of caesarean sections done over a 10-year period from 19952004.

Study Design: A retrospective observational study of the cases of caesarean sections over a decade.

Study setting: Holy Family Red Crescent Medical College Hospital.

Results: 23748 women were admitted in department of Obstetrics and Gynacology. Total deliveries were

Introduction:

Caesarean section rates have increased very rapidly over the past two decades both in developing and the developed countries $^{1}$. The rates increased from 18\% in 1997-1998 to $22 \%$ in $2000-2001$ in England ${ }^{2}$, from $10.7 \%$ in 1981 to $15.3 \%$ in 1995 in France $^{3}$ and from 5\% in 1973 to $15 \%$ in 2000 in Sweden ${ }^{4}$. Although stable for more than 15 years, the rate is still high at $26.1 \%$ in 2002 , in the

a. Dr. Rumana Nazneen, Associate Professor, Department of Obstetrics \& Gynaecology, Holy Family Red Crescent Medical College and Hospital.

b. Professor Rowshan Ara Begum, Prof. and Head, Department of Obstetrics \& Gynaecology, Holy Family Red Crescent Medical College and Hospital.

c. Dr. Kishwar Sultana, Assoc. Prof. Department of Obstetrics \& Gynaecology, Holy Family Red Crescent Medical College and Hospital.

Address of correspondence : Dr. Rumana Nazneen. Associate Professor, Department of Obstetrics \& Gynaecology. Holy Family Red Crescent Medical College and Hospital, Dhaka

Received: 17 December, 2009

Accepted: 29 December 2010
21149(89.05\% of total admission). The caesarean birth rate increased from $45.85 \%$ to $70.55 \%$. The indications varied a little in cases of malpresentation and eclampsia. APH and IUGR has risen a little (from 2.56 to 2.6 to 1.83 to $2.34 \%)$ respectively. But proportion of repeat caesarean section and that of presumed foetal distress (or less foetal movement) increased (from 25.99 to $31.45 \%$ and from 8 to $15 \%)$, recently the indication, as maternal choice is also coming up (from .43 to .8\%). The proportion has fallen in prolonged labour for cervical dystocia (from 17 to 2.6\%) and obstructed labour (from $4.6 \%$ to .36\%). The data were compared and analyzed by $\mathrm{Z}$ Test and corresponding Pvalue was calculated which was not significant.

Conclusion: Though caesarean section is a very safe intervention in obstetrics at present, crucial evaluation of the indications is advocated to reduce the rates of caesarean secion.

Keywords: Caesarean section rates, Indications.

(J Bangladesh Coll Phys Surg 2011; 29: 126-132)

United States ${ }^{5}$. This epidemic has also extended to the developing countries. Twelve Latin American countries have rates above $15 \%$, with a highest rate of $40 \%{ }^{6}$.

This continually rising caesarean birth rate is of increasing concern to both the professionals ${ }^{7,8}$ and the public. ${ }^{9}$ Over the last 30 years, there has been a public health concern about increasing Caesarean section rates. In 1985, the World Health Organization issued a consensus statement suggesting there were no additional health benefits associated with a Caesarean section rate above 10 to $15 \%{ }^{10}$. This also have generated wide spread concern and attempts to stop the reason to reduce this rate ${ }^{11,12,13}$. There are strong economic arguments for reduction of the rates ${ }^{14}$. Since early 1990s, emergency obstetric care (EmOC) in Bangladesh has improved to reduce the maternal mortality ratio. Along with other indicators of improved maternal care , there is a trend of rising caesarean section rates over the last 
decade affecting the economy of the country. According to demographic and Health Surveys conducted between 1993 and 2004, rate of caesarean section has risen from $2 \%$ to $6 \%$ which is more pronounced in urban area. In addition deficiency of adequate and efficient health care facilities in the rural settings increases the number of referral to the tertiary care centers. Analysis of the indications of these caesarean sections will reflect the causes of this increasing trend ${ }^{15}$.

\section{Objectives:}

- To assess caesarean section rates over the past decade.

- To find out the indications of caesarean section.

- To compare between the rates of Caesarean section.

\section{Materials and methods:}

It is a retrospective study of all the cases of caesarean sections over the decade done in Holy Family Red Crescent Medical College Hospital. Data of all deliveries from 1995 to 2004 were collected from the yearly statistical record book produced annually by the department and the hospital. Patient's individual data were collected from the hospital record room. This included total obstetric admission, total numbers of vaginal deliveries, instrumental deliveries, caesarean sections, their indications for admission and caesarean section were noted. The major contributing factors were compared and their proportions were calculated. When two or more contributing factors were present only one major indication was taken. The rising trends were shown in graph. The data were compared between 1995 to1999 and between 2000 to 2004. Then Z Test was done for statistical analysis. Corresponding $P$ value was calculated from the Tables.

\section{Inclusion and exclusion criteria:}

Figures contributing to a significant share in the indications of caesarean sections were included in the study. The rare and minor data were omitted.

\section{Results:}

The causes of caesarean sections were compared and shown in the tables and graphs. Table I shows that, total 23748 women were admitted in the obstetric unit over the decade. Numbers of the total deliveries were 21149 which comprised about $89 \%$ of total admission. The caesarean birth rate increased from $45.8 \%$ to $70.5 \%$ of total deliveries from 1995 to 2004. Spontaneous vaginal deliveries were reduced from $54.1 \%$ to $29.4 \%$. Table II shows that, major indications of caesarean sections, which varied a little in cases of malpresentation but proportion of repeat caesarean section increased from $25.9 \%$ to $31.4 \%$ and that of presumed foetal distress (and reduced foetal movement) from $8.3 \%$ to $15 \%$. Recently the indication as maternal choice is also rising up (from .4 to .8\%). The proportion has been fallen significantly in prolonged labour for cervical dystocia (from 17.1 to $2.6 \%$ ) \& obstructed labour (from 4.6 to .4\%). Proportion of IUGR has risen a little (from 1.8 to $2.3 \%$ ) and that of post dated pregnancy from 1.8 to $2.8 \%$. Percentage of APH remained unchanged (2.6\%). Percentage of CPD and Eclampsia has fallen from 6.9 to $4 \%$ and .8 to $.6 \%$ respectively over the years. Table III shows the comparative study of the total Caesarean sections and some important indications with their probability tests.

Figure 1a, shows the percentage of caesarean section rising from $45.8 \%$ in 1995 to $70.1 \%$ in 2004. Fig.-1b shows the percent of $\mathrm{C} / \mathrm{S}$ due to presumed foetal distress was highest in 2000 and 2002 (18\%) and lowest in 1997 (6.5\%). Fig.-1c shows the percentage of caesarean section due to repeat C/S was lowest in 2001 (17.2\%) and highest in 2004 (31.4\%). Fig.-1d shows the

percentage of C/S due to IUGR was lowest in 1999 (1.5\%) and highest in 2000 (4.2\%).

Table-IV shows, the proportion of patients which contributes to caesarean section. This assessment form is adopted internationally and is known as 10 group classification of Caesarean section ${ }^{10}$. It shows, the more caesarean sections performed in group 1 and 2 are likely to result in a larger group 5 in future if those women have further pregnancies. That means occurrence of increased caesarean sections in first pregnancies will result in increased number of repeat sections in the subsequent pregnancies which actually happened in our cases.

The data of 2004 was taken for assessment in 10 group classification for cesarean section in our setting. The overall caesarean section rate was $70.5 \%$. Out of these $5 \%$ were with spontaneous labour at term in first pregnancy; 4.3\% were with spontaneous labour at term in their subsequent pregnancies; $22.15 \%$ were with repeat section at term; $14.46 \%$ were in subsequent pregnancies at term either induced or elective caesarean section. Primi breech was $1.6 \%$, Multiparous breeches were $1.3 \%$, abnormal lie were $2.4 \%$, pregnancies at or above 36 weeks including previous caesarean section were $2.3 \%$. 


\section{Table-I}

Cumulative basic data from 1995 to 2004.

Values are shown as $n$ (numbers), and figure in parenthesis shows the percentage.

\begin{tabular}{lccccccccccc} 
& 1995 & 1996 & 1997 & 1998 & 1999 & 2000 & 2001 & 2002 & 2003 & 2004 & Total \\
\hline Total Obstetric cases & 2285 & 2391 & 2646 & 2707 & 2239 & 2445 & 2404 & 1992 & 2255 & 2384 & 23748 \\
Total deliveries & 2257 & 2149 & 2356 & 2413 & 2213 & 2193 & 2060 & 1795 & 1777 & 1936 & 21149 \\
Spontaneous vaginal & 1222 & 1028 & 1125 & 1155 & 987 & 802 & 693 & 571 & 611 & 569 & 8763 \\
Delivery \% & $(54.1)$ & $(47.8)$ & $(47.7)$ & $(47.9)$ & $(44.6)$ & $(36.6)$ & $(33.6)$ & $(31.8)$ & $(34.3)(29.4)$ & \\
InstrumentalVaginal & 13 & 7 & 7 & 9 & 3 & 7 & 2 & 0 & 2 & 1 & 51 \\
deliveries & $(6)$ & $(3)$ & $(3)$ & $(4)$ & $(1)$ & $(3)$ & $(1)$ & & $(1)$ & & \\
Caesarean section\% & 1035 & 1123 & 1224 & 1249 & 1226 & 1392 & 1367 & 1224 & 1224 & 1366 & 12430 \\
& $(45.8)$ & $(52.3)$ & $(52)$ & $(51.8)(55.4)$ & $(63.4)$ & $(66.3)$ & $(68.1)$ & $(68.8)$ & $(70.5)$ & \\
\hline
\end{tabular}

Table I - Shows that, out of 21149 deliveries, Cesarean section was 12430 that is almost $59 \%$ of total deliveries. It increased from $45.8 \%$ to $70.5 \%$ over the decade.

\section{Table-II}

\begin{tabular}{|c|c|c|c|c|c|c|c|c|c|c|}
\hline & 1995 & 1996 & 1997 & 1998 & 1999 & 2000 & 2001 & 2002 & 2003 & 2004 \\
\hline C/S (\%) & $\begin{array}{l}1035 \\
(45.8)\end{array}$ & $\begin{array}{c}1123 \\
(52.2)\end{array}$ & $\begin{array}{c}1224 \\
(51.9)\end{array}$ & $\begin{array}{c}1249 \\
(51.8)\end{array}$ & $\begin{array}{c}1226 \\
(55.4)\end{array}$ & $\begin{array}{l}1392 \\
(63.5)\end{array}$ & $\begin{array}{l}1367 \\
(66.3)\end{array}$ & $\begin{array}{c}1224 \\
(68.1)\end{array}$ & $\begin{array}{c}1224 \\
(68.3)\end{array}$ & $\begin{array}{c}1366 \\
(70.1)\end{array}$ \\
\hline epeat $\mathrm{C} / \mathrm{S}$ & 269 (25.9) & 255 (22.7) & $297(24.2)$ & 295 (23.6) & 274 (22.3) & 345 (24.8) & $236(17.2)$ & 293(23.9) & $374(30.5)$ & $429(31.4)$ \\
\hline & 131 (12.6) & $102(9.0)$ & $222(18.1)$ & 233 (18.6) & 149 (12.1) & $212(15.2)$ & 298(21.7) & $90(7.3)$ & 133(10.9) & 107(7.8) \\
\hline tal distress & $86(8.3)$ & 110 (9.8) & $80(6.5)$ & $90(7.2)$ & $152(12.4)$ & 249 (17.9) & $130(9.5)$ & $220(18)$ & 161(13) & 205(15) \\
\hline olong labour & $36(3.4)$ & $29(2.5)$ & $59(4.8)$ & $58(4.6)$ & $60(4.8)$ & $63(4.5)$ & $74(5.4)$ & $74(6.0)$ & $27(2.2)$ & $64(4.6)$ \\
\hline ech & 41 (3.9) & 55 (4.9) & $63(5.1)$ & 61 (4.8) & $100(8.1)$ & $70(5.0)$ & $45(3.3)$ & $44(3.6)$ & 21(1.7) & $57(4.1)$ \\
\hline $\begin{array}{l}\text { iled } \\
\text { duction }\end{array}$ & 38 (3.6) & $76(6.7)$ & $56(4.5)$ & 46 (3.7) & 47 (3.8) & $74(5.3)$ & $33(2.4)$ & $61(5)$ & $12(1)$ & $37(2.7)$ \\
\hline $\begin{array}{l}\text { ervical } \\
\text { ystocia }\end{array}$ & 177 (17.1) & $121(10.7)$ & $69(5.6)$ & $55(4.4)$ & $12(1)$ & $16(1.1)$ & 108(7.9) & $53(4.3)$ & $33(2.7)$ & $36(2.6)$ \\
\hline $\mathrm{OM}$ & $23(2.2)$ & $14(1.2)$ & 17(1.3) & $9(0.7)$ & $21(1.7)$ & $12(0.9)$ & $31(2.2)$ & $12(0.1)$ & $19(1.5)$ & $36(2.6)$ \\
\hline GR & $19(1.8)$ & $23(2.0)$ & $30(2.4)$ & $26(2.0)$ & $19(1.5)$ & $58(4.1)$ & $36(2.6)$ & $33(2.7)$ & $30(2.4)$ & $32(2.3)$ \\
\hline $\begin{array}{l}\text { bstructed. } \\
\text { abour }\end{array}$ & $48(4.6)$ & $31(2.7)$ & $22(1.7)$ & $50(4)$ & $40(3.2)$ & $42(3.0)$ & $24(1.7)$ & $33(2.7)$ & $3(0.2)$ & $5(0.4)$ \\
\hline lampsia & $9(0.8)$ & $17(1.5)$ & 20(1.6) & $19(1.5)$ & $9(0.7)$ & $5(0.3)$ & $12(0.9)$ & $11(0.9)$ & $6(0.5)$ & $9(0.6)$ \\
\hline $\mathrm{H}$ & $27(2.6)$ & $12(1.0)$ & 16(1.3) & $29(2.3)$ & $31(2.5)$ & 36 (2.5) & $25(1.8)$ & $25(2.0)$ & $27(2.2)$ & $35(2.6)$ \\
\hline $\mathrm{D}$ & $72(6.9)$ & $85(7.5)$ & $83(6.8)$ & $90(7.2)$ & $94(7.7)$ & $74(5.3)$ & $62(4.5)$ & $62(5.0)$ & $52(4.2)$ & $55(4.0)$ \\
\hline $\begin{array}{l}\text { ost Dated } \\
\text { regnancy }\end{array}$ & 19(1.8) & $16(1.4)$ & 23(1.8) & $29(2.3)$ & 22(1.8) & $17(1.2)$ & $32(2.3)$ & $27(2.2)$ & $37(3.0)$ & $38(2.8)$ \\
\hline Iaternal choice & - & - & - & - & - & $6(.4)$ & $6(.4)$ & $9(.7)$ & $10(.8)$ & $11(.8)$ \\
\hline
\end{tabular}

*PET- pre eclampsia, PROM- Prelabour rupture of membran, IUGR- Intra Uterine Growth Retardation, APH- Ante Partum Haemorrhage, CPD- Cephalo Pelvic Disproportion. 


\section{Table-III}

Comparative study of the total C/S \& some indications of C/S between 1995-1999 \& 2000-2004

\begin{tabular}{lcccc} 
Parameter & $\begin{array}{c}1995-1999 \\
(\text { mean })\end{array}$ & $\begin{array}{c}2000-2004 \\
(\text { mean })\end{array}$ & $\begin{array}{c}\text { Z Value } \\
(<1.96)\end{array}$ & $\begin{array}{c}\text { P Value } \\
(>.05)\end{array}$ \\
\hline Total C/S & 1171.7 & 1314.6 & 1.84 & \\
Repeat C/S & 278 & 335.4 & 1.39 & \\
C/S done for PET & 167.4 & 168 & .009 & $>0.05$ \\
C/S done for Post dated pregnancy & 21.8 & 30.2 & 1.39 & ( Not significant) \\
C/S done for Foetal distress & 103.6 & 122 & 0.39 & \\
C/S done for Prolonged labour & 48.4 & 60.4 & .786 & \\
C/S done for Obstructed labour & 38.2 & 21.4 & 1.30 & \\
\hline
\end{tabular}

Comparison of the above data showed that the value of $\mathrm{z}$ is not significant $(<1.96)$, corresponding $\mathrm{P}$ value is $>0.05$ (not significant).

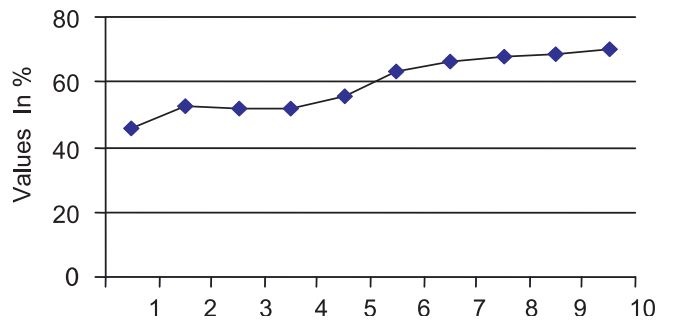

Fig.-1a : Comparative study of the Percentage of total no. of C/S from 1995-2004.

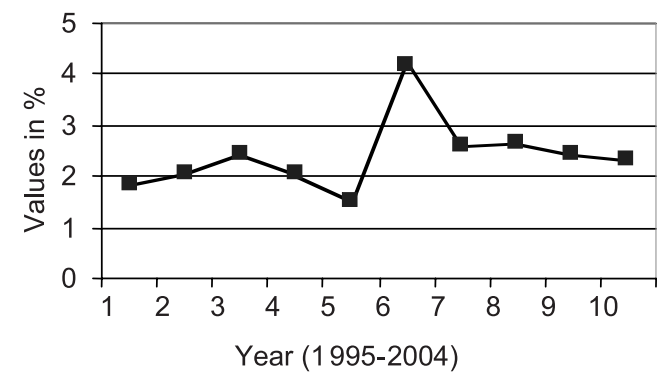

Fig.-1c: Comparative study of the \% of C/S due to IUGR (1995-2004).

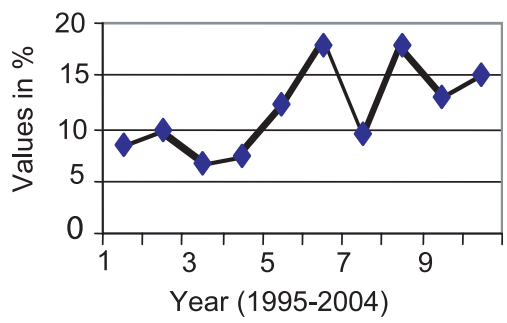

Fig.-1b: Comparative study of the Percentage of C/S from presumed Foetal distress (1995-2004).

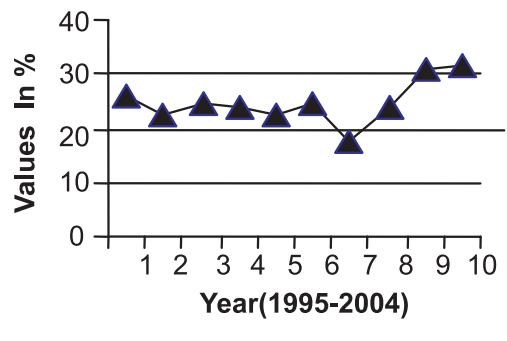

Fig.-1d: Comparative study of the \% of repeat C/S (1995-2004). 
Table-IV

\begin{tabular}{|c|c|c|c|c|c|}
\hline \multicolumn{6}{|c|}{ Overall Caesarean Section (CS) rate (\%)-1366/1936=70.55\% } \\
\hline & & $\begin{array}{l}\text { No. CS over } \\
\text { total No. } \\
\text { Women in } \\
\text { each group }\end{array}$ & $\begin{array}{l}\text { Relative size } \\
\text { of groups } \\
\text { (\%) }\end{array}$ & $\begin{array}{l}\text { CS rate in } \\
\text { each group } \\
(\%)\end{array}$ & $\begin{array}{l}\text { Contribution made } \\
\text { by each group } \\
\text { to the overall } \\
\text { CS rate of } \% \\
\end{array}$ \\
\hline 1. & $\begin{array}{l}\text { Nulliparous, single cephalic, } \\
\geq 37 \text { weeks, in spontaneous labour }\end{array}$ & $98 / 233$ & $\begin{array}{c}12 \% \\
(233 / 1936)\end{array}$ & $\begin{array}{r}42.06 \% \\
(98 / 233)\end{array}$ & $\begin{array}{c}5.06 \% \\
(98 / 1936)\end{array}$ \\
\hline 2. & $\begin{array}{l}\text { Nulliparous, single cephalic, } \\
\geq 37 \text { weeks, induced or CS before labour }\end{array}$ & $303 / 438$ & $\begin{array}{c}22.60 \% \\
(438 / 1936)\end{array}$ & $\begin{array}{c}69.17 \% \\
(303 / 438)\end{array}$ & $\begin{array}{c}15.65 \% \\
(303 / 1936)\end{array}$ \\
\hline 3. & $\begin{array}{l}\text { Multiparous (excluding previous CS), } \\
\text { single cephalic, } \geq 37 \text { weeks, in } \\
\text { spontaneous labour }\end{array}$ & $84 / 348$ & $\begin{array}{c}17.97 \% \\
(348 / 1936)\end{array}$ & $\begin{array}{c}24.13 \\
(84 / 348)\end{array}$ & $\begin{array}{c}4.33 \% \\
(84 / 1936)\end{array}$ \\
\hline 4. & $\begin{array}{l}\text { Multiparous (excluding previous CS), } \\
\text { single cephalic, } \geq 37 \text { weeks, induced } \\
\text { or CS before labour }\end{array}$ & $\begin{array}{l}280 / 544 \\
429 / 501\end{array}$ & $\begin{array}{c}28.09 \% \\
(544 / 1936) \\
25.87 \%\end{array}$ & $\begin{array}{c}51.47 \% \\
(280 / 544) \\
85.62 \%\end{array}$ & $\begin{array}{c}14.46 \% \\
(280 / 1936) \\
22.15 \%\end{array}$ \\
\hline 5. & $\begin{array}{l}\text { Previous CS, single cephalic, } \\
\geq 37 \text { weeks }\end{array}$ & & $(501 / 1936)$ & $(429 / 501)$ & $(429 / 1936)$ \\
\hline 6. & All nulliparous breeches & $31 / 43$ & $\begin{array}{c}2.22 \% \\
(43 / 1936)\end{array}$ & $\begin{array}{r}72.09 \% \\
(31 / 43)\end{array}$ & $\begin{array}{c}1.60 \% \\
(31 / 1936)\end{array}$ \\
\hline 7. & $\begin{array}{l}\text { All multiparous breeches } \\
\text { (including previous CS) }\end{array}$ & $26 / 57$ & $\begin{array}{c}3 \% \\
(57 / 1936)\end{array}$ & $\begin{array}{r}45.61 \% \\
(26 / 57)\end{array}$ & $\begin{array}{c}1.34 \% \\
(26 / 1936)\end{array}$ \\
\hline 8. & $\begin{array}{l}\text { All multiple pregnancies } \\
\text { (including previous CS) }\end{array}$ & 23/31 & $\begin{array}{c}2 \% \\
(31 / 1936)\end{array}$ & $\begin{array}{l}74.19 \% \\
(23 / 31)\end{array}$ & $\begin{array}{c}1.18 \% \\
(23 / 1936)\end{array}$ \\
\hline 9. & $\begin{array}{l}\text { All abnormal lies } \\
\text { (including previous CS) }\end{array}$ & $47 / 47$ & $\begin{array}{c}2 \% \\
(47 / 1936)\end{array}$ & $\begin{array}{c}1 \% \\
(47 / 47)\end{array}$ & $\begin{array}{c}2.42 \% \\
47 / 1936)\end{array}$ \\
\hline & $\begin{array}{l}\text { All single cephalic, } \geq 36 \text { weeks } \\
\text { (including previous } \mathrm{CS} \text { ) }\end{array}$ & $45 / 142$ & $\begin{array}{c}7 \% \\
(142 / 1936)\end{array}$ & $\begin{array}{c}31.69 \% \\
(45 / 142)\end{array}$ & $\begin{array}{c}2.32 \% \\
(45 / 1936)\end{array}$ \\
\hline
\end{tabular}

The 10 Group classification in 2004, Holy Family Red Crescent Medical College Hospital.

\section{Discussion:}

During the decade there was around $24.7 \%$ increase in the caesarean section rates in our setting which is comparable with an study done in our country ${ }^{15}$. Regarding the other findings, rate of instrumental deliveries decreased from 13 to 1 (.6\% to $0 \%)$ which explains the rising trends of the caesarean sections. Yet this is becoming increasingly safe for women and children. The rate of pelvic floor problems (particularly urinary incontinence) is substantially higher in women who had vaginal deliveries than in women who had caesarean sections $16,17,18$. Although this evidence is discussed in the context of elective caesareans, it can be seen as challenging the professional perspective on the risk-benefit ratio for caesarean sections compared with vaginal delivery for specific indications ${ }^{19}$. _Caesarean sections do involve certain risks, but the operation is much safer than in previous years. At the same time, the increased awareness of the complications of the vaginal delivery ${ }^{20}$ and the increase in women's dissatisfaction with long labours of vaginal delivery have resulted in obstetricians having a lower threshold for advising delivery by caesarean section-21-22. In recent years, the incidence of Caesarean section for maternal request is gradually rising. Whether or not a Cesarean section should be carried out on a request is yet a controversial issue ${ }^{23}$.

Studies shows that maternal request was one of the main indications for C/S (23\%) in 1996 24. Defensive 
obstetrics is another common reason for high rates of caesarean section. It has been observed that $82 \%$ of physicians performed $\mathrm{C} / \mathrm{S}$ to avoid negligence claims ${ }^{25}$. Repeat caesarean sections contributed 29\%, presumed foetal distress contributed $22 \%$, failure to progress in labour contributed $20 \%, 88 \%$ of breech babies, low birth weight $39 \%$, and maternal choice (7\%).

Other studies showed, the main indications of caesarean section were, repeat caesarean section (34.3\%), failure of progress (19.3\%) and fetal distress $12.9 \%{ }^{23}$, another study done in our country showed repeat caesarean section decreased about $2.95 \%$ over the period of 8 years ${ }^{15}$. In our study the rate actually increased because the same patient attends the hospital for her successive deliveries. The rate of foetal distress and malpresentation in the same study showed a little increase (3.79\% and $2.53 \%$ respectively) and considerably greater increase in caesarean section done for obstructed labour and eclampsia $(2.79 \%, 3.75 \%$ respectively). But our study showed considerably greater increase in foetal distress and malpresentation (6.7\%, $.2 \%)$ and a decrease in obstructed labour and eclampsia $(4.2 \%, .2 \%)$. The reason for this difference is the socio economical status of the patients attending both the settings. But overall there has been an increase in the rate of cesarean section in many countries of the world. The rising number of indications for cesarean section, the use of fetal monitors, the current medico-legal climate, and the indications for performing caesarean section has changed a lot in recent years and keep on changing for varied circumstances. Most caesarean section is currently performed to benefit the fetus, not the mother. This study was done to compare the changes in rates of caesarean section with a view to analyze and reduce the rates if possible. Although the reasons are multifactorial in most of the cases, and also the number of referral and workload pattern of the tertiary hospital, as well as the socio economical status of the patients , their demands for the service are the important factors for consideration, the findings of this retrospective study suggests that the rate of the caesarean section could be reduced in certain categories of patients.

The 10 group classification is currently being used internationally ${ }^{10}$, and provides helpful information in the assessment of the causes of caesarean section rates. We have taken the data of 2004 for comparison. Unnecessary interventions in group 1 and 2 should, preferably be avoided. In '10 group classification', it has been shown that the category of pregnancy, the previous obstetric record of the woman, the course of labour and delivery, and the gestational age of pregnancy can add to the incidence of caesarean section. From these concepts and their parameters, the 10 groups were formed. Monthly critical analysis of these 10 groups is required including comparison with previous months in the same units and also in other units helps in analyzing the outcomes.

It is observed that the overall percentage of caesarean section has risen up. This could be due to the fact that more referral cases are appearing in commencing years. Also the less complicated population is being diverted elsewhere in nearby more inexpensive settings.

\section{Conclusion and recommendations:}

Caesarean section is undoubtedly a very safe intervention in obstetrics now a days. But yet, there is some morbidity even in tertiary care hospitals. With the advent of modern techniques of the procedure and also the safer anaesthesia, rates of caesarean sections has raised. More over patients with a previous caesarean sections are more likely to undergo a repeat section in the subsequent pregnancies mostly due to safety issues. As a result we have to perform a $3^{\text {rd }}$ or $4^{\text {th }}$ caesarean section which certainly carry a high morbidity risk. Also from the 10 group classifications we can categorize the cases which might undergo a caesarean section. So the situation definitely calls for an evaluation to catch hold the string of this rising trend.

Indications for doing caesarean section should be very cautiously evaluated. Mothers who opt for caesarean section just for their will needs be counseled properly. Labour analgesia also needs to be improved. Minimization of the costs of delivery can have a positive impact on the consumers. Trial for vaginal birth after caesarean section can also reduce the rate of repeat caesarean section, especially in tertiary care settings under proper vigilance. Periodic caesarean section evaluation sessions need to be more critically analyzed.

\section{Acknowledgement:}

I specially thank Dr. Zaida Rahman, Assoc. prof. Pharmacology Enam medical college, for her support in statistical analysis. Also I thank the staff of the hospital record room and the patients who helped in documentation of the data. 


\section{Limitations of the study:}

The study was a retrospective one and some of the indications did not reveal the actual proportion since only the main indication was documented out of multiple reasons for doing the operations. Also new tables regarding the complications of cesarean sections could not be given due to lack of raw data.

\section{References:}

1. Kim C.Y, Ko SK, Kim K.Y. Are league tables controlling epidemic of caesarean sections in South Korea? RCOG, BJOG; 2005; 112, 607-611;

2. Mayor S. Caesarean section rate in England reaches 22\%.BMJ 2002; 324:1118.

3. Guihard P, Blondel B, Trends in risk factor for caesarean sections in France between 1981 and 1995; lessons for reducing the rates in future. Br J Obstet Gynaecol 2001; 108(1): 48-55.

4. Odlind V, Haglund B, Pakkanen M, Otturblad Olausson P. Deliveries, mothers and newborn infants in Sweden, 19732000.Trends in obstretics as reported to the Swedish Medical Birth Registar. Acta Obstet Gynaecol Scand 2003; 82(6):516528.

5. Arias E, Mac Dorman MF, Strobino DM, Guyer B. Annual summary of vital statistics-2002. Paediatrics 2003; 112; 1215-1230.

6. Belizan JM, Althabe F, Barros FC, et al. Rates and implications of caesarean sections in Latin America: ecological study. BMJ 1999; 319: 1397-1402.

7. Lomas J. Holding back the tide of caesarean section. BMJ 1988; 297: 569-570.

8. Bottoms SF, Rosen MG,Sokol RG.The increase in the caesarean birth rate. $N$ Engl J Med 1980; 302: 559-563.

9. Shearer E C. Education of vaginal birth after caesarean section. Birth 1982; 9:31-34.

10. Robson, Michel S. Can the high Caesarean section rates be reduced? Recent advance in Obstetrics and Gynaecology. 2004; 22:71-84.

11. Pettiti DB, Cefalo RC, Sharpiro S, Whally P. Hospital maternal mortality in United States: Time trends in relations to methods of delivery. Obstet Gynaecol 1982; 59:6-12.

12. Rubin GL, Peterson HB, Rochat RW, McCarthy BJ, Terry JS. Maternal death after Caesarean section in Georgia. Am J Obstet Gynaecol. 1981; 139:681-685.
13. Lilford RJ, Van Coeverden DGHA, Moore PG, Bingham P. The relative risk of Caesarean section (intrapartum and elective) and vaginal delivery, a detailed analysis to exclude the effect of medical disorders and other acute pre existing physiological disturbances. Br.J Obstet Gynaecol. 1990; 97: 883-892.

14. Shy KK, Logerfo JP, Karp LE. Evaluation of elective repeat caesarean section as a standard of care; an application of decision analysis. Am J Obstet Gynaecol 1981; 139: 123129 .

15. Salma R, Sehereen FS, Md. Anwar HM, Anwara B. The rising trend for caesarean birth rate in a tertiary referral and teaching hospital. Bangladesh J Obstet Gynaecol. 2000; 15(1):1523.

16. Sultan AH, Kamm MA, Hudson CN, Thomas JM, Bartram CI, Anal Sphincter disruption during vaginal delivery. N Engl J Med. 1993; 329:1906-1911.

17. Thomas J, Paranjothy S. Royal College of Obstetricians and Gynaecologists Clinical Effectiveness Support Unit. National Sentinel Caesarean Section Audit Report. London (UK): RCOG Press; 2001.

18. Lawson DH., Sherman V., Hollowell J. The General Practice Research Database. Scientific and Ethical Advisory Group. QJM 1998; 91: 445-52.

19. Victrup L, Lose G, Rolf M, Barfoed K. The symptoms of stress incontinence caused by pregnancy or delivery in primiparas. Obstet Gynaecol. 1992; 79: 945-949.

20. Mac Arthur C, Bick DE, Kighly MR, Faecal incontinence after child birth. Br J obstet gynaecol 1997; 104:

21. Lawson DH, Sherman V, Hollowell J, The general practice research Database. Scientific and Ethical Advisory group QJM .1998; 91:445-52.

22. Paterson B S. Should doctors perform an elective caesarean section on request? Yes, as long as the women is fully informed. BMJ. 1998; 317: 462-463.

23. Amu O, Rajendran S, Bolaji I, Should doctors perform an elective caesarean section on request? Maternal choice alone should not determine method of delivery. BMJ 1998; 317: 463-465.

24. Mukherjee S N. Rising cesarean section rate J Obstet Gynecol India, July/August 2006; 56; 4 : 298-300.

25. Birchard K. Defence Union suggests new approach to handling litigation costs in Ireland. Lancet 1999. 354: 1710. 